\title{
Critical reflection on critical thinking and TEM tests of English major students' performance
}

\author{
Ya Luo \\ Guizhou Minzu University, Guiyang City, Guizhou Province, People's Republic of China
}

\begin{tabular}{|c|c|}
\hline Article Info & ABSTRACT \\
\hline Article history: & Critical thinking is now called for modern age of educational \\
\hline Received July 4, 2021 & management, due to education can prepare children and citizen to face \\
\hline Revised August 16, 2021 & with uncertainty of changing world. Complexity of modern world is \\
\hline Accepted September 9, 2021 & $\begin{array}{l}\text { adapting with a ton of knowledge and millions of situations that shape } \\
\text { our children to face with uncertainty. The article aims to critical }\end{array}$ \\
\hline $\begin{array}{l}\text { Keywords: } \\
\text { assessment } \\
\text { critical thinking } \\
\text { language learning } \\
\text { reflection }\end{array}$ & $\begin{array}{l}\text { reflection on critical thinking and TEM tests of English major students' } \\
\text { performance. Skills-based learning in terms of English for minority } \\
\text { group is important for quality of education. Educators could not ignore } \\
\text { the phenomenon that students lack of critical thinking through various } \\
\text { sources of learning and testing. The point of reflection needs to } \\
\text { cultivate students' abilities in independent thinking, innovation, } \\
\text { analysis and critical awareness in order to achieve a better goal in } \\
\text { language teaching. }\end{array}$ \\
\hline
\end{tabular}

This is an open access article under the $\underline{C C B Y-S A}$ license.

Corresponding Author:

Ya Luo

Guizhou Minzu University,

Guiyang City, Guizhou Province,

People's Republic of China

E-mail: christineluoya@hotmail.com

\section{INTRODUCTION}

In the recent years, a large number of researches focus on the training college students in field of critical thinking. The awareness of international society with rapidly changed and economical competition is raised to educational management. Due to critical thinking is the most important criteria for students to face with modern era with compete in the rapid developing society. It has been one goal of higher education preparing citizen to have thinking skills for life and career. The law of higher education of People's Republic of China (1999) points out that the task of higher education in China is to cultivate advanced professional talents with innovative spirit and practical ability. Thinking is an important tool for success in design and develops novice ideas that can leads to the innovations.

However, in fact Chinese college students lack the ability of critical thinking and the ability of innovation. Critical thinking is not new to education, Dewey (1933) firstly pointed out that active, persistent, and careful consideration of a belief or supposed form of knowledge lies in light of ground which support it and the further conclusions to which it tends. Pragmatic education has greatly influenced the development of cultivation of thinking intelligence. Students exposed situations and develop the way to solve problem in critically. It has long 
been emphasized as a crucial skill for academic success and social life in western educational domain (Elder \& Paul, 1998).

Yuanshen (1998) calls it "critical thinking absence disease". In addition, for a long period, cultivating students' ability in critical thinking has been ignored, in particular English major students as no matter teachers or the syllabus focus on language skills. In order to achieve the goal of language teaching and satisfy the needs of students in this competitive society, scholars have realized the importance of applying critical thinking skills in class with teaching pedagogy combined and pay more attention to cultivate students' innovation ability inside and outside classroom.

Current situation of introduction critical thinking skills in Chinese universities "English Teaching Syllabus for English Majors" (2000) pointed out that we should strengthen the cultivation of students' critical thinking ability and innovation ability to consciously train students' analysis and synthesis, abstraction and generalization, multi-angle analysis and other thinking ability and the innovative ability and guide them to find the problems and solve the problems in the teaching of specialized courses. With the connotation of the syllabus, teachers need to focus on not only language skills but also critical thinking skills and ability of innovation. However, numerous scholars and researchers found that college students in China lack abilities of innovation, analysis, evaluation and critical thinking. Educators should pay more attention to English major students as they think there are many problems within their teaching methods (Zhen, 2018).

Traditional teaching methods, for instance traditional teaching method or other methods with only teachercentered, it cannot answer how students enhance their thinking abilities. Students could not have the awareness of independent thinking as the teacher-centered methods emphasize too much on language skills. For example, memorizing grammatical structures and vocabulary are easy teaching strategies, but difficult incubate students in thinking. Excellent English talents are expected to possess solid basic knowledge, overall language capacity and also the critical and innovative spirit $(\mathrm{Hu}, 2008)$. Students are facing with new modern technology and communications, they have to use more critical thinking to react with big data and information to make them more accurate consideration (Dostál et.al., 2017).

The qualities of English major are expected to be solid English language basics, systematic professional knowledge, profound humanistic quality and in particular, the excellent critical thinking capability and communicative competence (Sun, 2010). Moreover, English major students in China less in the critical thinking ability, and further illustrated that when it was time for them to argue in a debate, to make a statement in an article or to ask questions in a lecture, English major students often had nothing to say or even if they had a vague idea, they often did not know where to start (Huang, 1998).

However, under the facts in China, some researchers pointed out the significance of cultivate students' ability in critical thinking. Liu (2013) asserts that mastering linguistic knowledge and being able to use English do not equate with successful language learning; to become proficient in English, EFL learners also need to apply critical thinking in the use of the target language. Wen (2009) also stated "Critical thinking is conscious thinking through certain criterion of thinking, and ultimately making rational judgment, and then improving the rational thinking, and reflective thinking is the thinking skill. It takes a logical method as the foundation, combined with the people's everyday thinking and psychology, the development tendency of a series of thinking skills and ability, which are extremely useful thinking skill, so that we can distinguish the real and useful information from the vast amounts of information data." What we can see from the researches is reform of language teaching is urgent.

\section{CRITICAL THINKING AND INFLUENCE OF TEM TESTS}

Critical thinking can be promoted through multi-design of learning and assessment. It needs to be significant issue for modern classroom (Setyarini et.al., 2018). Students learn new experiences based on curriculum, but the communication and thinking should have distinctive implemented in classroom. The process of thinking is influenced by communication as well as one of learning environment. From what these scholars have been discussed, it can be seen that Chinese English major students lack abilities of critical thinking and innovation, therefore they could not have good performance in all kinds of language learning objectives, no matter in language learning or assessment.

TEM tests are designed as an achievement to measure the overall English proficiency of undergraduates majoring in English Language and Literature in China and to decide whether these students meet the requirements of English language abilities and professional knowledge of English as specified in the National College English 
Teaching Syllabus for English Majors (NACFLT, 2004). TEM tests aim to test the comprehensive ability of English major students in Chinese universities with very limited testing opportunities. Each student has two opportunities in each test. The proficiency level of test takers which is reported on certificate includes three ranks, that is, "excellent" (score 80 or above), "good" (score between 70 and 79) and "pass" (score between 60 and 69). As the TEM tests are seen as the highest authoritative test in China within English major students, instruction to TEM tests is vital to every English major student as it is the test to prove their ability in English language. Moreover, TEM tests are considered as the most difficult English test in China, we can see the framework of each test by the Table 1 and 2 .

Table 1 Framework of TEM8

\begin{tabular}{|c|c|c|c|c|c|}
\hline Part & \multicolumn{2}{|c|}{ Test item } & Format & Percentage of & Time (min.) \\
\hline \multirow{3}{*}{ I } & \multirow{3}{*}{$\begin{array}{l}\text { Listening } \\
\text { comprehension }\end{array}$} & mini-lecture & Gap filling & $10 \%$ & \multirow{3}{*}{25} \\
\hline & & interview & Multiple choice & $5 \%$ & \\
\hline & & news & Multiple choice & $5 \%$ & \\
\hline II & \multicolumn{2}{|c|}{ Reading comprehension } & Multiple choice & $30 \%$ & 45 \\
\hline III & \multicolumn{2}{|c|}{ Proofreading and Error Correction } & Gap filling & $15 \%$ & 15 \\
\hline IV & \multicolumn{2}{|l|}{ Translation } & translation & $15 \%$ & 20 \\
\hline $\mathrm{V}$ & \multicolumn{2}{|l|}{ Writing } & Passage writing & $20 \%$ & 45 \\
\hline \multicolumn{4}{|c|}{ Total } & $100 \%$ & 150 \\
\hline
\end{tabular}

Table 2 Framework of TEM4

\begin{tabular}{|l|l|l|l|c|c|}
\hline Part & \multicolumn{2}{|c|}{ Test item } & Format & $\begin{array}{c}\text { Percentage of } \\
\text { scoring }\end{array}$ & Time (min.) \\
\hline \multirow{2}{*}{ I } & $\begin{array}{l}\text { Listening } \\
\text { comprehension }\end{array}$ & dictation & Writing passage & $10 \%$ & 10 \\
\cline { 2 - 5 } & conversation & Multiple choice & $20 \%$ & 20 \\
\hline II & Language usage & Multiple choice & $20 \%$ & 10 \\
\hline III & cloze & Gap filling & $10 \%$ & 10 \\
\hline IV & Reading comprehension & Multiple choice & $20 \%$ & 35 \\
\hline V & Writing & Writing passage & $20 \%$ & 45 \\
\hline \multicolumn{2}{|c|}{ Total } & $100 \%$ & 130 \\
\hline
\end{tabular}

What we can see from the two tables is the stressful procedures of different parts. Each part needs to be finished on time as the teachers will collect answer sheets separately, which means student could not spend too much time on a particular part. It is thought that too much stress is given in the test procedures.

TEM tests in Guizhou Minzu university, the pass rate of TEM4 is about $15 \%$ and $8 \%$ for TEM 8 . Take the results into consideration, we can see a great gap between Guizhou Minzu university and other universities. Based on teaching experience, firstly, compare with other universities in big cities, lacking educational resources is the biggest problems in my province. For example, English teachers lack opportunities to improve themselves within teacher training programmes. Consequently, new teaching methods, teaching techniques or teaching materials cannot be directly conducted in class. Secondly, more than half of students come from the rural areas of my province, and nearly $70 \%$ of them are ethnic minorities with their own languages. English acquisition has been ignored in these regions for a long time. Students and their parents hold the view that English is a foreign language and there is no need to have a good acquisition of it.

Moreover, the teachers who teach English in the middle schools in these areas lack language skills as these areas are short of English teachers, comparing with big cities, every student who hold bachelor degree can be an English teacher in rural areas. Thirdly, the motivation of students is low in my school. As I mentioned before, students and their parents consider English is a foreign language and there is no need to have a good acquisition of it, in addition English major students are easy to find a job in primary and middle schools. Thus, a lot of students want to be in English major but lack of motivation as the shortage of English teachers in my province. As an old saying "interest is the most powerful motivation of learning", without interest, students could not have a good 
performance in language acquisition, especially in assessment. With my consideration, I would make my point clearly - no interest, no critical thinking ability.

\section{GAP OF TESTING AND THINKING}

At a result, some scholars pay attention to cultivate students in critical thinking through new teaching methods in class. Zhou (2018) pointed out eight keys to cultivate students critical thinking ability-"a. paying attention to the skills of asking questions in the Classroom, b. changing the mode of classroom teaching, c. creating a relaxing teaching atmosphere, $d$. constructing a new Student evaluation system, e. reasonable design of classroom teaching, f. improving teachers' critical thinking ability, g. raise students' awareness of critical thinking ability training, h. PBL teaching method." Wang (2017) also claimed that "The instructors also need to develop their own critical thinking capability from the following aspects. First, they are supposed to reflect their own understanding of critical thinking and how it is applied to the discipline and the course. Second, they will lead the students how to thinking along a critical thinking pattern. Third, with regard to the assessment criteria, the instructors shall learn that students are best evaluated by how well they think and behave beyond the class rather than they are scored just through the final exams." From the results of these researches, we can find both teachers and students have to develop critical thinking skills. A question has raised here, how to properly combine tests and instruction of critical thinking skills.

After reading the articles, we found almost all researchers focus on the reform of teaching pedagogy in order to cultivate students' ability in critical thinking. They chose mixed research methods with teaching experiment, questionnaire, interview and so on. Through teaching experiment, researchers can easily find the problems of students and then design appropriate teaching methods to motivate students in learning language skills in order to achieve the teaching goal. Importantly, another point that I want to emphasis is the critical thinking ability of English teachers as they play a vital role in teaching and in guiding students. Teachers in China not only play a role in teaching, but also in building students 'morality. With the changes of students, teachers need to change first and be the guide.

However, with authors teaching experience, if we want to cultivate students' ability in critical thinking, we, as teachers, need to have some changes in teaching. And I need to stress some points. At first, teacher-centred teaching methods are the main teaching methods in many Chinese universities within English major students. It is considered that grammar-translation method is conducted in many universities, the teachers directly give the target content to students and ask them to memorize.

Zhou (2018) illustrated, no matter teaching atmosphere, students and teachers abilities or teaching methods have to change and find a way to improve all aspects of language learning. Secondly, teachers in China have to follow the syllabus which is designed under the core curriculum of the nation. Cotemporary courses with textbooks are required in teaching, consequently teachers could not have too much freedom to design their class. Moreover, teachers could not set up too many activities inside classroom as they need to finish the teaching tasks in the syllabus. Thirdly, almost in all Chinese universities, the size of class is around 40students, with two hours or four hours language teaching in each subject per week, English teachers could not take care of every students and have a reasonable evaluation of students' performance in class. With a long period of traditional cramming teaching method, students would lose interests in leaning language. In a result, English major students would not have a good performance in learning language, in particular assessment, based on the three facts.

In addition, as far as I am concerned, test is the biggest barrier for English teachers to cultivate students' abilities in critical thinking and innovation as students would only focus on the grammatical structures and vocabulary-the way of passing examination. With memorizing and emphasizing on testing skills, students would lack abilities in analysis, identification, evaluation and critical awareness. They could not achieve to have personal opinions or ask questions in or outside classroom. As a result, they would not have a habit of independent thinking and critical thinking. Students and teachers will pay more attention to the result of assessment, not the usage of language. Take it into consideration, students would not have great achievement in future language learning or language usage as they think the learning is exam-oriented.

\section{CONCLUSION}

We can see the framework of TEM tests, writing is considered as an important part in the tests. In the part, students could not have a good performance as they do not have logic in constructing a passage. With what above 
mentioned, both teachers and students lack the ability of critical thinking, thus without no reform of language teaching in English majors, we could not achieve the goal of language teaching and the goal in "English Teaching Syllabus for English Majors" (2000). Students would not have the ability in critical thinking. With the consideration of research interest, five questions have raised.

1. How to improve students' performance in TEM4 and TEM8 by instructing the critical thinking skills ?

2. How could the teachers build their own teaching model in instructing critical thinking skills?

3. How could critical thinking skills influence on the learning strategy of English major students in my province?

4. How do English teachers cultivate their abilities in critical thinking?

5. Which aspect of critical thinking do Chinese English major students lack?

With the perspectives of the law of higher education of People's Republic of China (1999) and the New Syllabus (2000), critical thinking can be seen as an important ability to college students. And it is crucial to develop students' ability in critical thinking, even it is a long-term process. Based on the facts in Chinese university classrooms, we, as teachers, could not ignore the phenomenon that students lack of critical thinking ability. We need to cultivate students' abilities in independent thinking, innovation, analysis and critical awareness in order to achieve a better goal in language teaching (Gustine, 2018).

\section{REFERENCES}

Dewey, J. (1933). How we think: A restatement of the relation of reflective thinking to the education process. Boston: D.C. Heath \& Company.

Dostál, J., Wang, X, A. Steingartner, W. \& Nuangchalerm, P. (2017). Digital intelligence-new concept in context of future school of education. Proceedings of ICERI2017 Conference. Seville, Spain. $16^{\text {th }}-18^{\text {th }}$ November 2017. Pp. 3706 - 3712.

Elder, L., \& Paul, R. (1998). The role of Socratic questioning in thinking, teaching, and learning. Clearing House, 71(5), 297-301.

Gustine, G. G. (2018). A survey on critical literacy as a pedagogical approach to teaching English in Indonesia. Indonesian Journal of Applied Linguistics, 7(3), 531-537.

Huang, Y. S. (1998). Absence of critical thinking. Foreign Language Teaching and Research, 7, 1-2.

Hu, W. Z. (2008). A review and reflections on English major teaching reform in China. The World of Foreign Language, 5,10-15.

Huang, Y. (1998). The lack of critical thinking. Foreign Languages and Their Teaching, 20(7), 2-18.

Setyarini, S., Muslim, A. B., Rukmini, D., Yuliasri, I., \& Mujianto, Y. (2018). Thinking critically while storytelling: Improving children's HOTS and English oral competence. Indonesian Journal of Applied Linguistics, 8(1), 189-197.

Sun, Y.Z., \& Linin, J. (2010). A Probe into the English Major Curriculum Pattern. Foreign Language Teaching and Research, 4, 50-61.

Wang, X. (2017). A study on developing critical thinking of English major students through the teaching of comprehensive English. Theory and Practice in Language Studies, 7(8), 670-676.

Wen, Q. F., Wang J. Q., Zhao C. R., Liu Y. P., \& Wang H. M. (2009). Constructing the theoretical framework of Chinese foreign language college students' critical thinking ability measuring tool. Foreign Language Circles, 1, 37-43.

Zhou, Z. (2018). A study on cultivation of critical thinking ability of English majors. Theory and Practice in Language Studies, 8(3), 349-353. 